\title{
THE IMPACT OF USERS ADVOCACY ON CONFORMITY, REINFORCEMENT AND BEHAVIOUR EXCHANGE AMONGST ROAD USERS IN PORT HARCOURT
}

\author{
${ }^{1}$ Emmanuel, John Matthew \& ${ }^{2}$ Kalu, Sylva E. \\ ${ }^{1,2}$ University of Port Harcourt
}

\begin{abstract}
This study examines the extent to which advocacy as a social marketing tool can help bring about road users' rules conformity, reinforcement and behavioural exchange. From a population of 11,760,871, a sample of 420 was derived using Krejcie and Morgan sample table. The theoretical framework was anchored on theory of reasoned action and social cognitive theory. The stated hypotheses were tested using Multiple Regression and from the findings, we realized that all the hypotheses tested had a significant coefficient and associated p-values. For these reasons, the stated null hypotheses were rejected. The study further recommends that social marketing efforts if applied and implemented appropriately can help the society in changing the behaviour of the citizens.
\end{abstract}

Keywords: Users' advocacy, rules conformity, reinforcement, behavioural exchange, road users 
Journal DOI: www.doi.org/10.46654/ij.24889849

\section{Introduction}

Behaviour change is the bedrock of all marketing efforts (Andreasen, 2002) whether it is private or public sector marketing. Marketing activities that focus on brands of products, services and ideas are aimed at changing behaviour or initiating action for patronage (Kotler, 2003). According to MacFadyen, Stead and Hastings (1999), "marketing has been remarkably successful in encouraging people to buy products such as Coca Cola and Nike trainers, so, the argument runs, it can also encourage people to adopt behaviours that will enhance their own - and their fellow citizens' - lives". Marketing practitioners target customers with the focus on modifying their behaviour for some benefits. This behaviour change primarily triggers action to buying the products, services or idea, is at the centre of the marketing programmes. It is in similar manner that social marketing has as its core focus, behaviour change (NSMC, 2017), which is about let-go a behaviour, sustaining the behaviour, modifying or better still adopting a behaviour. Social marketing therefore will be to communicate, encourage, advocate, educate and empower the customer to change behaviour for the benefits of himself/herself and the society (Gordon, Carrigan \& Hastings, 2011).

The need for profit making is a fundamental reason why marketing practitioners learn human behaviour (Hastings \& Saren, 2003). To acquire proper understanding of human behaviour, they draw from other bodies of knowledge such as psychology, economics, sociology, political sciences, anthropology and communication theory (Serrat, 2010). Behaviour however has become a pillar to which profit making in commercial marketing is hinged upon. Similarly, behaviour is the anchor point on which social marketing practitioners put all their efforts upon starting from planning through implementation to evaluation. The bottom-line is to influence the behaviour to change for some benefits. McKenzie-Mohr (2000) asserts that "changing individual behaviour is central to achieving a sustainable future."

The essence of social marketing is behaviour change which is achieved by influencing people for improvement of their general wellbeing such as health, enhancement of their financial status, ensures prevention of injuries, protection of the environment, contributing to the development of the community and many other efforts that will drive better lives in the society (Hastings \& Saren, 2003). Essentially social marketing does not only stop at ensuring that behaviour change is achieved, it goes further to make sure that there is sustainability in the behaviour that has been changed (Andreasen, 2002). This effort is usually pursued vigorously because the benefits are usually enormous, and it goes beyond the individual to impact on the society. One can then agree that, in as much as social marketing efforts produce some gains, the beneficiaries will invariably be inclined to support any of such efforts and activities going forward. When the support is there, there is the tendency that patronage can be influenced positively. If this chain of reaction occurs, it will result in some kind of patronage coming out from the target customers. The benefits are what the traditional concept of marketing points out that organisations' marketing activities are driven by the objective to satisfy customers' needs (Wood, 2014).These are all efforts geared toward ensuring that the target audience yields to the desire of the marketer. To collaborate this, Smith and Schenieder (2009) are of the view that marketing is associated with manipulation of the customers' behaviour to yield to the desired action which will satisfy the customers and benefit the organisation.

One of the fundamental tasks of government is to reduce road crashes to the barest minimum and keep the highways safe at all times (FRSC Act, 2007). Surprisingly, road crashes in 
Journal DOI: www.doi.org/10.46654/ij.24889849

Nigeria shows that non adherences on rules conformity such as speed violation is the leading cause (National Bureau of Statistics, (NBS), 2016: NBS, 2017 \& NBS, 2018). Data on road crashes from the Nigeria Bureau of Statistics shows that in 2016 speed violation contributed $38.86 \%$ of road crashes. This increased to $42.69 \%$ in quarter 1 of 2017 , moved further higher to $44.44 \%$ in quarter 2 of 2017 and by quarter 2of 2018, speed violation had increased to $50.65 \%$.

The key concern and focus of this study are to investigate and possibly establish how best social marketing variables such as advocacy could impact on behaviour modification among road users. Social marketing is widely used to influence behaviour modification in the area of health involving issues such as HIV and AIDS, Obesity consciousness, and anti-alcohol drinking and conservation of environment (Gallopel-Morvan, 2008; Foxall, Oliviera-Castrol \& James, 2006).

\section{Research Hypotheses}

Ho1: There is no significant relationship between road users' advocacy and rules conformity among road users in Port Harcourt, Nigeria.

Ho2: There is no significant relationship between road users' advocacy and reinforcement among road users in Port Harcourt, Nigeria.

Ho3: There is no significant relationship between road users' advocacy and behaviour exchange among road users in Port Harcourt, Nigeria.

\section{Theoretical Framework}

\section{Theory of Reasoned Action (TRA)}

In 1967, Fishbein first introduced the TRA in the pursuit to understand the relationship between attitude and behaviour (Ajzen \& Fishbein, 1980). The focus was an attempt to explain the interrelationship between attitude, belief, intention and behaviour. This theory has evolved and been majorly used in predicting behaviour intention. Ajzen (1991) points out that this theory explains that the volitional behaviour of a person is predicated on the person's behavioural intention. This theory indicates that the behavioural intentions which are immediate antecedents to the behaviour of a person are hooked on salient information and beliefs in relation to the possibility that performing a particular behaviour would result to a specific outcome. Fishbien and Ajzen (1975) assert that behavioural intention refers to the attitude of a person towards exhibiting volitional behaviour with the normative impact and could be termed to be the person's normative belief. However, behavioural intention of customers have been addressed by the human behaviour model of Ajzen and Fishbien (1980) through the Theory of Reasoned Action, and it considers all external variables that could influence the individual's behaviour. Besides, attitude of the individual and subjective norms influences the behavioural intention of the individual. Attitude is determined by the individual perception of the likely outcome of an action.

The essence of TRA as part of the theoretical foundation is to help explain the individual's candid behaviour and the individual volitional control (Sheppard, Hartwick\& Warshaw, 1988). To better understand behaviour is to analyze behavioural intention of the individual (Doran, L., Stone, V., Brief, A., Arthur, P. \& George, J., 1991).The TRA in this work 
Journal DOI: www.doi.org/10.46654/ij.24889849

provides the platform on which the behaviour of road users could be understood and stimulus for behaviour modification for safer road usership could be administered appropriately.

\section{Social Cognitive Theory (SCT)}

Social Cognition is about the way and manner whereby individuals analyze, interpret, remember and make use of information about the social environment (Franzoi, 2000). The theory explains the possibility of the individual to adopt a fresh behaviour considering environmental factors and personal capabilities to voluntarily exhibit the fresh desirable behaviour. Kotler and Lee (2000) assert that the theory elucidates "the likelihood of adopting the behavior is determined by perceptions that benefits outweigh the costs and belief in selfefficacy". The individual is more focused on observing the environment and learn from it. It considers the environment as platform where one observes the actions of others and learns from the outcome of others' behaviour.

SCT revolves around the understanding that there has to be gaining and maintaining attention of others, retention of the occurrence, reproducing of the occurrence and some motivation to reproduce the behaviour (Lefebvre, R. C., 2000). The theory points to the fact that there is a tendency of reciprocity. The individual evaluates the benefits that he or she will gain in giving off a behaviour. The benefits reciprocate for the obstinate behaviour that is expected to be given away.

Social Cognitive theory states that likelihood of adopting the behaviour is determined by perception that benefits or outweighs the cost and belief in self-efficacy. This is very similar with the Social Learning Theory (Bandura, 1997) which focuses on building up the target audience's sense of self-efficacy, that is, the belief that they can ensure that the behaviour change happen.

\section{Advocacy and Behaviour Modification}

Customer advocacy is unique approach to customer relationship and customer services. Urban (2003) states that the power of the customer is growing, hence "customers now have tools that inform them of the true state of affairs. This power enables them to avoid the pushy messages of marketers, make their own decisions and determine what to buy". Modern customers have through the help of development in businesses and technology, now have easy access to information, have access to wide range of alternatives, can transact businesses very easy and there is increasing level of communications and interaction between the customers and the organisations. According to Susanta, Alhabsji, Idrus \& Nimran (2013), "advocacy is the customer's desire to provide strong recommendations and praise for suppliers of products or services to other customers".

Lawer and Knox (2006) define customer advocacy as "an advanced form of market orientation that responds to the new drivers of consumer choice, involvement and knowledge". They also point to the same fact that customer advocacy primary goal is to enhance deeper customer relationships by developing new levels of conviction, trust and commitment. Customer advocacy is also aimed at developing mutual interaction, understanding, transparency and partnership with customers.

The traditional marketing and selling thinking are that when the company creates awareness and inform people enough about a product or service, some proportion of the population will make their way through the buying process in the purchase funnel to buy the product or 
Journal DOI: www.doi.org/10.46654/ij.24889849

service (Savary, 2008). Advocacy require some engagement and affinity with the products or services and even with the organisation offering them. Actually, representing the interest of the customer is the essence of Customer Advocacy (Urban, 2003). This requires providing the customers with honest, open and complete information about product and service.

The focus in advocacy in social marketing vary from one organisation to the other because it is hinged on what the organisation deemed to be best for its potential and prospective customers. Advocacy is anchored on experience of the people which is the story the customers have about the product or services. This therefore shows that advocacy is tied to relationship. Advocacy is the outcome of an excited relationship borne out of the emotional connection the customers have with the product or services. For this to genuinely happen therefore, there has to be the absence of frictions, dissonance and complains from the customers about the organisation and its products or services. The relationship and experience have to be smooth, friendly and memorable. Customer advocacy can genuinely be a stop-gap and long-term measure to improve customer relationship, satisfaction, retention and profitability (Bailey \& Jensen, 2006).

The advocacy role emanates from the fact that marketers or other staff members of an organisation could affect the customers' experience and the perception that the customers have about the organisation. In such situations where the customer experience is not managed and causing the customer to be exposed to the organization's complexities, inefficiencies, gaps and dissonance, the role of customer advocacy becomes very inevitable (Bailey \& Jensen, 2006). Unpleasant and difficult experience could would make the customer to apply unnecessary extra energy and time to navigate the organization to get things done or issues resolved. Advocacy helps to avoid the waste of these valuable efforts and time.

The current market trend shows that many consumers now have easy access to authoritative new media and information tools which help them to compare products and services (Pitt, Berthon, Watson, \& Zinkhan, 2002; Wind \& Rangaswamy, 2001). This new trend has spurred up organisations to respond by developing customer advocacy strategies and practices (Sawhney and Kotler, 2001; Mitchell, 2001; McKenna, 2002; Baker, 2003; Urban, 2004). Customer advocacy is simple, operating with strategies of how to assist consumers to find and execute their desired solution in the process buying their favourite product and services; it will be easier for an organisation to earn their long-term trust and loyalty with their customers (Urban, 2004).

In general business transactions, customers will always look forward to easy and possibly seamless means of getting their products and services without hassles. This kind of expectation is not usually the case. Urban (2003) states in his opinion that creating strong levels of trust by advocacy will be more rewarding in the economic sector that characterized by the following features: "1) the products are complex, 2) the products require high customer involvement, 3) customers face a risk of loss if they do not select the right product, 4) many alternative products exist, and 5) large amounts of information are available".

Advocacy according to Bailey and Jensen (2006) will thrive in organisations where there is complexity in organisational structure; such that the customers encounter some difficulties to navigate through before they could get things done, customer experience are managed holistically and where the products or services are complex such that multiple people are required to explain and deliver such products or services. 
Journal DOI: www.doi.org/10.46654/ij.24889849

Urban (2004) is of the opinion that advocacy is based on maximizing the customers' interests and partnering with customers for better relationship, loyalty and profitability. The execution of customer advocacy needs special skills and experience in various aspects of human interactions. The competencies to carry out successful customer advocacy could be found in people who have honesty and straight forward behaviour, with interpersonal management and communication capabilities, good business sense and judgment and have competencies in time and project management. In creating customer advocacy, Lee (2013) explains that one needs to create a great proposition, and this will drive powerful advocates even from among the top executives of the organisation. Bailey and Jensen (2003) put forward a practical advocate framework which involves customer segmentation, engagement, escalation, response management, handling customer experience and internal management review. These elements involve customer classification which is essential in understanding and managing issues linked to personality, experience, emotions, dissonance and choice. There reality in customer advocacy follows the principle that 'one size does not fit all', hence customer segmentation and profiling become very important for the organisation to have. The customers could believe in the quality and responsiveness of the organisation, but then exceptional case could occur, then the customers would need to meet or talk to customer advocates. It is important that the customers understand that they have a right, according to Bailey and Jensen (2003) that "If ever you feel we are not meeting your expectations, or that an exception has occurred and our standard operating procedures have failed you, feel free to engage a customer advocate". Advocacy requires some level of intimacy and mutual interaction. The segmentation will help in opening up the profiles of the customer base and assigning best-fit or appropriate in-house Advocates. Segmentation of the customer would significantly help in customer advocacy because the approach and interactions would have been predetermined by the segmentation.

The essence for engagement is for better customer relationship and loyalty would result in profitability and success. This intention has caused organisation to resort to advocacy strategy which require experienced customer consultants (Achrol and Kotler, 1999) and in some organisations they hire trusted advisor to execute that role (Sheth, Sisodia and Sharma, 2000). It is important to point out that this role seeks to assist customers to make convincing and pleasant purchasing decisions and to maximize their benefits obtained from the products or services.

Engagement naturally flows from the understanding of the customers' segmentation profile. It is imperative customer engagement is professional and properly managed because customers' power is consistently growing as a result of technology, media fragmentation and availability of alternation (Urban, 2003). Then determine when and how to engage the customer. Engagement here is with the purpose of resolving issues, complains and frictions, and reversing unpleasant experience to endurable memorable pleasant experience which would trigger better words of mouth communication from the customers to other prospects.

Escalation in advocacy is concerned with expanding the scope of handling or managing customer issues. Customer dissatisfaction could arise from diverse angles just as the customers themselves are diverse in nature. The capacity to singularly resolve all the issues may not possibly reside in one person, the available and wise thing to do is to escalate the issue or challenge. The advocate needs to have a wide knowledge and good work network within and outside the organisation. This means that at any point the customer advocate has a comprehensive list of who to call to fix a problem at hand. Experts in various specialties are 
Journal DOI: www.doi.org/10.46654/ij.24889849

easily contacted for solutions where the advocate at the hub and centre cannot handle the issue immediately. Escalation of customer issues can be thrown up even up to the point of csuite, provided the customer is happy, satisfied and goes back with endurable pleasant experience. When this happens, the customer is likely to be converted to become the organisation's advocate.

There is the response planning, analysis and execution stage in advocacy process and this involves the development of a model chronicling previous customers' issues and problems and breaking down the response, handling and resolution mode. For example, the history of customer complaints, inquiries and other challenging issues could be outlined indicating the dissonance timeframe of identification of the issues. When this is done, we would easily get summary of situation, core cause of the issues or problem, timeframe within resolution of the problems, what were the likely factors linked to the problems and the action taken to resolve the issues. It is important as indicated by Bailey and Jensen (2003) that after resolving the initial challenges it is critical and necessary that the customer is re-engaged and the process of the problem solving explained and frankly discussed, in order to re-enact trust and confidence thereby strengthening the customer's experience.

Managing of customers' experience requires meeting with them either individually or as a group. In the process of discussion with the customer there may be identification of some issues that require additional investigation depending on the problem. In going through the list of actions that created the customers' dissatisfaction situation, it is important that the contributing factors are shared with the customers. This has to be done with some level of tact and care in doing, however, there is need to do this with full disclosure of the issues surrounding the problem so that reoccurrence would be avoided. The internal management review is an essential facet of customer advocacy process because it brings to bear and to the knowledge of the management team, all issues, challenges, core problems, peripheral factors in customer dissatisfactions, timing and action deployed in resolving the issues. In handling all of these concerns, Bailey and Jensen (2003) are of the view that there has to be internal review meetings which have to be held frequently at least weekly with proper participation of particularly the customer advocates in attendance. When such meetings are held, it is pertinent that the agenda should include review of all issues and challenges required for advocacy engagement in the organisation.

Arising from the above, it considered that advocacy could impact on the behaviour modification of customers who are the road-users in this study and invariably on rules conformity, reinforcement and behaviour exchange.

For purpose of clarity the target population of this study is the group of people to whom the variables of this study were applied to. In this circumstance therefore, we expected that the results of our study would be applied to all road users in Nigeria; hence this remained our target population for this study. The study population on the other hand is the usership of vehicles on the road who are customers to FRSC in Port Harcourt, Nigeria. This definition implies that our population for the study was all the drivers of motor vehicles on the road in Port Harcourt, Nigeria.

The population from which the sample was drawn from is a finite one, which is the drivers of motor vehicles in Port Harcourt, Nigeria, and the information on it was obtained from the National Bureau of Statistics. A finite population is simply, a population where specific and accurate figure are applicable (Nwankwo, 2016). For this study, the sampling frame was the 
population of vehicles which are driven in Nigeria. The National Bureau of Statistics (NBS, 2018) provides the human population figure of $198,000,000$ persons with a 0.06 vehicle per population and stating clearly the motor vehicle population to be $11,760,871$. This is the official figure of the numbers of vehicles on the Nigerian roads as at Quarter 2, 2018. The spilt of these vehicles on the road is as follows:

Commercial vehicles

Private vehicles

Government/Diplomatic vehicles

\section{$57.7 \%$.}

$40.98 \%$

$1.32 \%$.

Drilling down into the number of people who patronize or are customers of the FRSC, we considered the number of Drivers' Licenses produced for issuance. Taking into consideration that our geographical scope for this study is the Port Harcourt, Nigeria, the NBS latest data indicates that for Port Harcourt, Rivers State, for Quarter 2, 2018, the customers of FRSC are11,862 going by the number of Licenses issued. This is our study population.

The Krejcie and Morgan (1960) Sample Determination Table gives us 375 and the researcher decided to boost the sample by $10 \%$ (37.5). That is $375+38$ will give us 413 . Therefore, this research was on sampled 420 practicing drivers who are owners of valid FRSC Driver's License who we have defined as customers of the FRSC.

Data Analyses and Findings

\begin{tabular}{|l|l|l|l|l|}
\hline Ho1 & $\begin{array}{l}\text { There is no significant relationship between } \\
\text { advocacy and rules conformity }\end{array}$ & 0.589 & 0.000 & Reject \\
\hline $\mathbf{H o}_{2}$ & $\begin{array}{l}\text { :There is no significant relationship between } \\
\text { advocacy and reinforcement }\end{array}$ & 0.608 & 0.000 & Reject \\
\hline $\mathbf{H o}_{3}$ & $\begin{array}{l}\text { There is no significant relationship between } \\
\text { advocacy and behaviour exchange }\end{array}$ & 0.625 & 0.000 & Reject \\
\hline
\end{tabular}

Test for hypothesis one reveals a regression coefficient (R) of 0.589 and a coefficient of determinant ( $\mathrm{R}$ square) of 0.347 . This implies that advocacy affects rule conformity by $34.6 \%$

Our test of hypothesis two give a regression coefficient (R) of 0.608 and a coefficient of determinant ( $\mathrm{R}$ square) of 0.369 . This therefore explains that advocacy on the road users, impacts on the reinforcement of their behaviour by $36.8 \%$.

For the third hypothesis $\left(\mathbf{H o}_{3}\right)$, the result of the analysis gives a regression coefficient $(\mathrm{R})$ of 0.625 while the coefficient of determinant ( $\mathrm{R}$ squared) is 0.391 . This result therefore indicates that advocacy correlate with behaviour exchange; that is, there is a $38.9 \%$ impact of advocacy on behaviour exchange among the road users in Port Harcourt, Nigeria. 


\section{Conclusion}

The purpose of this research was to empirically investigate and establish if there is any relationship between social marketing and behaviour modification among road users. The study results have revealed that advocacy correlate at high coefficient levels with the dimensions of behaviour modification which are rules conformity, reinforcement and behaviour exchange signifying that there is a significant relationship between social marketing and behaviour modification among road users in Port Harcourt, Nigeria.

Drilling down into the results of the study, the regression coefficients obtained were high alongside the zero probability that the null hypotheses not occurring and hence the alternative taken. These results point to the fact the objectives of this research are achieved because the results show that social marketing correlate significantly with rules conformity among road users. Furthermore from the study output is the fact that social marketing is significantly related to rules conformity and reinforcement among the road users, drawing from the coefficient and the p-values obtained when the measures of the social marketing are analysed with reinforcement as a dimension of behaviour modification. On the desire for the research to determine the relationship between social marketing and behaviour exchange, the results have shown that there is a significant relationship between social marketing and behaviour exchange among road users in Port Harcourt, Nigeria.

\section{Recommendations}

1. Application of technology using social marketing approach will greatly help in behaviour modification of the road users thereby bringing sanity and safety on the road.

2. This work has shown clearly that social marketing efforts if applied and implemented appropriately can help the society in changing the behaviour of the citizens. Stretching beyond the behaviour of road users, further studies could be conducted to establish any other area of human endeavour that social marketing would be useful for the benefit of the society. 


\section{References}

Andreasen, A. (1995).Marketing Social Change: Changing Behavior to Promote Health, Social Development and the Environment. San Francisco; Jossey Bass Publishers.

Ang. L. \& Buttle, F (2006). Customer retention management processes: A quantitative study. European Journal of Marketing. 40 ( 1 \& 2),83-99.

Anshari, M., Almunawar, M. N., Low, P. K. C., \& Wint, Z. (2012). Customer empowerment in healthcare organisations through CRM 2.0: Survey results from Brunei tracking a future path in e-health research. Austrian Journal of South- East Asian Studies, 5(1), 139-151.

Armstrong, G., Kotler, P., Cunningham, P., Mitchell, P. \& Buchwitz, L. N. (2007). Marketing: An introduction. (2nd Canadian ed.). Toronto, Canada: Pearson Prentice Hall.

Asiegbu, I. F. (2006). Pillars for social research and framework for brandism. In Agundun, P. U., Eketu, C. A. \& Asawo, S. P. (2006). World explorer social and managerial paradigmic Tackles and Tickles with financial research showcase. Port Harcourt, Nigeria: Sonite Publishers.

Asiegbu, I. F. (2009). Sales Force Competence Management and Marketing Performance of Industrial and Domestic Product Firms in Nigeria. A Ph.D Dissertation Presented to the Post Graduate School, River State University of Science and Technology, Port Harcourt, Nigeria.

Asika, N. (2008). Research methodology in the behavioural science. Lagos, Nigeria: Longman Publishers.

Awa, H. O. (2002). Strategic marketing promotion mix: Concepts and application to consumption related decision. Port Harcourt, Nigeria: CeeKay Publishers.

Bailey, C. \& Jensen, K. (2006). Customer advocacy. A customer centric white paper.Hudson, NH:Customer Centricity Inc.

Baker, M. J, \& Saren, eds. M. (2010) Marketing theory: A student text, 2nd ed. London: Sage Publications.

Baker, S.L. (2003). New consumer marketing: Managing a living demand system. Chichester: John Wiley\& Sons.

Bandura, A. (1997). Self-efficacy: The exercise of control. New York, NY: FreemanPress.

Barsky, J. \& Nash, L. (2003). Customer satisfaction; Applying concepts to industry-wide measures. Cornell Hotel and Restaurant Administration Quarterly, 4, 173-183.

Bei, L. T.\& Yu-Ching Chiao, Y. C. (2006). The determinants of customer loyalty: An analysis of intangiblefactors in three service industries, International Journal of Commerce and Management, 16(3/4), 162 - 177.

Bickel, W. K. \& Vuchinich, R. E., eds. (2000), Reframing Health Behavior Change with Behavioral Economics. Mahwah, NJ: Lawrence Erlbaum Associates. 
Biong, H. (1993). Satisfaction and loyalty to suppliers within the grocery trade.European Journal of Marketing, 27 (7), 21-36.

Bearden, I \& LaForge, (2007). Marketing: Principles and perspectives (5th ed.). New York, NY: McGraw-Hill Companies.

Belch, G. E. \& Belch M. A. (2008).Advertising and Promotion: An Integrated Marketing Communications Perspective (8th ed.). New York, NY: McGraw-Hill.

Hastings, G \& Saren, M., (2003). The critical contribution of social marketing: Theory andapplication. Marketing Theory. 3 (305) DOI: 10.1177/147059310333005. Retrieved from http//mtq.sagepub.com/content/3/3/305.

Hastings, G., Stead, Stead, M. \& Webb, J. (2004) Fear appeals in social marketing:Strategic and ethical reasons for concern. Psychology \& Marketing, 21(11): $\quad 961-986$.

Helmig, B. \& Thaler, J. (2010). On the effectiveness of social marketing - what do we really know? Journal of Nonprofit \& Public Sector Marketing, 22 (4), 264-87.

Hodge, D. R. \& Gillespie, D. F. (2003). Phrase completion: An alternative to Likert scales. Social Work Research. 27 (1); 45-55.

Holbrook, M. B. (1994). The nature of customer's value: An axiology of service in consumption experience. In R.T. Rust, \& R. L. Oliver (Eds.), Service quality: New directions in theory andpractice. Thousand Oaks, CA: Sage Publications.

Homburg, C., Koschate, N\& Hoyer, W. D.(2005. Do satisfied customers really pay more? A study of the relationship between customer satisfaction and willingness to pay. Journal of Marketing, American Marketing Association. 69 (2), 84-96.

Hoque, S. R. (2013). Effect of Reinforcement on Teaching - Learning Process.ISOR Journal of Humanities and Social Science. 7(1), 13-16.

Housten, F. S. \& Gassenheimer, J. B. (1987). Marketing and exchange. Journal of Marketing, $51,3-18$.

Huang, M. H. \& Yu, S. (1999). Are consumers inherently or situationally brand loyal? A set intercorrelation account for conscious brand loyalty and nonconscious inertia. Psychology and Marketing, 16 (6), 534-544.

Hunter, G. L. \& Garnefeld, I. (2008). When does Consumer Empowerment Lead to Satisfied Customers? Some Mediating and Moderating Effects of the EmpowermentSatisfaction Link. Journal of Research for Consumer. 15, 1-14.

Igwe, S. R. (2016). Brand management: Concept, theory and practice. Port Harcourt, Nigeria: Celwil Publishers.

Ilieska, K. (2013). Customer satisfaction index: As a base for strategic marketing management. TEMJournal, 2 (4), 327-331.

Inamullah, K., (2012). Impact of customer satisfaction and customers retention on customer loyalty. International Journal of Scientific and Technology Research, $\quad 1(2), \quad 106-$ 110. 
Jashi, C. (2018). Applications of social marketing in road safety of Georgia. World Academy of Science, Engineering and Technology International Journal of Economics and Management Engineering,12 (4), 522-525.

Jobber, D. (2004). Principle and practice of marketing (4th ed.). London, UK; The McGrawHill Company.

Jones, M. A., and Suh, J. (2000). Transaction-specific satisfaction and overall satisfaction: An empirical analysis. Journal of Services Marketing, 14(2), $147-159$.

Kumar, R. (2011). Research methodology: A step-by-step guide for beginners. (3rd ed,). London: Sage Publications

Lawer, C. \& Knox, S. (2006). Customer advocacy and brand development. Journal of Product \& Brand Management, 15 (2), 121-129.

Lee, B. (2013). How to create powerful customer advocates: All the way to the C-Suite. The Hidden Wealth of Customers. Boston: Harvard Business Review Press.

Lee, N. \& Kotler, P. (2012). Social marketing: Influencing behaviors for good (4th. ed.). Los Angeles, LA: Sage.

Lee, N. R., Rothschild, M. L., \& Smith, W. (2011). A declaration of social marketing's unique principles and distinctions. Unpublished manuscript, March.

Leedy, P. D. \& Ormrod, J. E. (2010). Practical research: Planning and design (9th ed.). Upper Saddle River, NJ: Prentice Hall.

Leedy, P.D \& Ormrod, J. E. (2016). Practical research: Planning and design. Boston: Pearson Inc.

Lefebvre, R. C. (2000). Theories and models in social marketing. In P. N. Bloom \&

G.

T. Gundlach (Eds.), Handbook of Marketing and Society. Newbury Park, CA: Sage Publications

Lennon, R., Rentfro, R.\&O’Leary, B. (2010). Social marketing and distracted driving behaviors among young adults: The effectiveness of fear appeals. Academy of Marketing Studies Journal, 14 (2), 95-113.

Lovelock, C., \& Wirtz, J. (2011). Services marketing: People, technology and strategy ed.). Upper Saddle River, NJ: Pearson Prentice Hall.

Lussier, R. N. (2009). Management Fundamentals (4th ed.).South-Western: Cengage Learning. 